Article

\title{
N6-Benzyladenosine Derivatives as Novel $N$-Donor Ligands of Platinum(II) Dichlorido Complexes
}

\section{Pavel Štarha, Igor Popa, Zdeněk Trávníček * and Ján Vančo}

Regional Centre of Advanced Technologies and Materials, Department of Inorganic Chemistry, Faculty of Science, Palacký University, 17. listopadu 12, CZ-77146 Olomouc, Czech Republic; E-Mails: pavel.starha@upol.cz (P.S.); igor.popa@upol.cz (I.P.); jan.vanco@upol.cz (J.V.)

* Author to whom correspondence should be addressed; E-Mail: zdenek.travnicek@upol.cz; Tel.: +420-585-634-352; Fax: +420-585-634-954.

Received: 3 May 2013; in revised form: 7 June 2013 / Accepted: 8 June 2013 /

Published: 14 June 2013

\begin{abstract}
The platinum(II) complexes trans- $\left[\mathrm{PtCl}_{2}\left(\mathrm{~L}_{\mathrm{n}}\right)_{2}\right] \cdot x \mathrm{Solv} \mathbf{1}-\mathbf{1 3}$ (Solv $=\mathrm{H}_{2} \mathrm{O}$ or $\mathrm{CH}_{3} \mathrm{OH}$ ), involving N6-benzyladenosine-based N-donor ligands, were synthesized; $\mathrm{L}_{\mathrm{n}}$ stands for N6-(2-methoxybenzyl)adenosine ( $\mathbf{L}_{\mathbf{1}}$, involved in complex $\left.\mathbf{1}\right)$, N6-(4-methoxybenzyl)adenosine ( $\left.\mathbf{L}_{\mathbf{2}}, \mathbf{2}\right)$, N6-(2-chlorobenzyl)adenosine $\left(\mathbf{L}_{\mathbf{3}}, \mathbf{3}\right)$, N6-(4-chlorobenzyl)adenosine ( $\left.\mathbf{L}_{\mathbf{4}}, \mathbf{4}\right)$, N6-(2-hydroxybenzyl)adenosine ( $\left.\mathbf{L}_{\mathbf{5}}, \mathbf{5}\right)$, N6-(3-hydroxybenzyl)adenosine ( $\left.\mathbf{L}_{6}, \mathbf{6}\right)$, N6-(2-hydroxy-3-methoxybenzyl)adenosine ( $\left.\mathbf{L}_{7}, \mathbf{7}\right)$, N6-(4-fluorobenzyl)adenosine ( $\left.\mathbf{L}_{\mathbf{8}}, \mathbf{8}\right)$, N6-(4-methylbenzyl)adenosine $\left(\mathbf{L}_{\mathbf{9}}, \mathbf{9}\right)$, 2-chloro-N6-(3-hydroxybenzyl)adenosine ( $\left.\mathbf{L}_{\mathbf{1 0}}, \mathbf{1 0}\right)$, 2-chloro-N6-(4-hydroxybenzyl)adenosine $\left(\mathbf{L}_{\mathbf{1 1}}, \mathbf{1 1}\right)$, 2-chloroN6-(2-hydroxy-3-methoxybenzyl)adenosine $\left(\mathbf{L}_{12}, \mathbf{1 2}\right)$ and 2-chloro-N6-(2-hydroxy-5methylbenzyl)adenosine $\left(\mathbf{L}_{\mathbf{1 3}}, \mathbf{1 3}\right)$. The compounds were characterized by elemental analysis, mass spectrometry, IR and multinuclear $\left({ }^{1} \mathrm{H}-,{ }^{13} \mathrm{C}-,{ }^{195} \mathrm{Pt}\right.$ - and $\left.{ }^{15} \mathrm{~N}-\right)$ and two-dimensional NMR spectroscopy, which proved the N7-coordination mode of the appropriate N6-benzyladenosine derivative and trans-geometry of the title complexes. The complexes 1-13 were found to be non-toxic in vitro against two selected human cancer cell lines (HOS and MCF7; with $\mathrm{IC}_{50}>50.0 \mu \mathrm{M}$ ). However, they were found (by ESI-MS study) to be able to interact with the physiological levels of the sulfur-containing biogenic biomolecule L-methionine by a relatively simple 1:1 exchange mechanism (one $\mathrm{L}_{\mathrm{n}}$ molecule was replaced by one L-methionine molecule), thus forming a mixed-nitrogen/sulfur-ligand dichlorido-platinum(II) coordination species.
\end{abstract}


Keywords: platinum(II) complexes; transplatin derivatives; N6-benzyladenosine derivatives; multinuclear NMR; antitumor activity

\section{Introduction}

Despite a formidable intensity of research and development in the field of metallopharmaceuticals, the group of platinum(II) complexes still leads in the number of treated patients, as well as in the number of marketed drugs and yearly sales [1]. The success of this group began with the discovery of anticancer activity of the cis-isomer of Peyrone's salt [diammine-dichloridoplatinum(II)] [2], known as cisplatin, by the group of Rosenberg et al. [3], while the other, biologically nearly inactive trans-isomer (transplatin) remained just a scientific oddity for a long time. The conundrum of the inactivity of the trans-isomer was unravelled by the discoveries during the latest 20 years (for comprehensive reviews see [4,5] and the references therein), which showed that trans-platinum inspired complexes, such as those involving the aromatic heterocyclic ligands [6], aliphatic amines [7], or iminoether ligands [8], could exhibit cytotoxicity comparable to that of cisplatin, and also that some of these biologically active species could circumvent the mechanisms of resistance to cisplatin [9,10]. These discoveries fired up the recent development in the area and proved that trans-platinum complexes must be considered as biologically relevant, even if the mechanisms of their action are much more complex than in the case of cisplatin.

N6-benzyladenine and its substituted-benzyl derivatives represent the plant hormones from the group of aromatic cytokinins [11]. The free bases are responsible for their physiological action, while the ribosides, i.e., N6-benzyladenosine and its substituted-benzyl derivatives, are one of the transport forms of the mentioned phytohormones. The quoted N6-benzyladenosines have been shown as in vitro antitumor active substances against various types of human cancer cell lines [12,13]. However, from the coordination chemistry point of view, only two papers dealing with the transition metal complexes with N6-benzyladenosine and its substituted-benzyl derivatives acting as $\mathrm{N}$-donor ligands have been published to date. Concretely, Waysbort et al. studied the dinuclear rhenium acetato-bridged complexes with N6-benzyladenosine [14], while Trávníček et al. described a series of iron mixedvalence complexes involving N6-(substituted-benzyl)adenosine derivatives and their in vitro antitumor effect on four human cancer cell lines [15]. The $\left[\mathrm{FeCl}_{3}\left(\mathrm{~L}_{8}\right)_{2}\right]$ complex, which involves N6-(4fluorobenzyl)adenosine symbolized as $\mathbf{L}_{\mathbf{8}}$ in this work, was found to be moderately effective against human osteosarcoma $\left(\mathrm{HOS} ; \mathrm{IC}_{50}=8.0 \mu \mathrm{M}\right)$, human myelogenous leukemia $\left(\mathrm{K} 562 ; \mathrm{IC}_{50}=9.0 \mu \mathrm{M}\right)$ and human adenocarcinoma (MCF7; $\mathrm{IC}_{50}=16.0 \mu \mathrm{M}$ ) cancer cells. These findings led us to study the utilization of in vitro anticancer active organic molecules (N6-benzyladenosine derivatives) as N-donor ligands of the coordination compounds of the biologically more perspective transition metal (i.e., platinum). We chose thirteen synthetically relatively easily obtainable N6-benzyladenosine derivatives, which represent two types of compounds, i.e., N6-(substituted-benzyl)adenosine derivatives $\left(\mathbf{L}_{\mathbf{1}}-\mathbf{L}_{\mathbf{9}}\right)$ and 2-chloro-N6-(substituted-benzyl)adenosine derivatives $\left(\mathbf{L}_{\mathbf{1 0}}-\mathbf{L}_{\mathbf{1 3}}\right)$, which act as $\mathrm{N}$-donor ligands within the structures of trans-platinum(II) dichlorido complexes (1-13). The complexes were screened for their in vitro antitumor activity against two human cancer cell lines (HOS and MCF7) to find out 
whether the complex formation may enhance the cytotoxic effect of the ligands involved in the prepared complexes.

\section{Results and Discussion}

\subsection{Characterizations and General Properties of the Complexes}

The trans- $\left[\mathrm{PtCl}_{2}\left(\mathrm{~L}_{\mathrm{n}}\right)_{2}\right] \cdot x \mathrm{Solv}$ complexes 1-13 $\left(\mathrm{Solv}=\mathrm{H}_{2} \mathrm{O}\right.$ or $\left.\mathrm{CH}_{3} \mathrm{OH}\right)$ were prepared as white powders. Although, the preparation of cis-isomers was the main goal of this work, only the pure trans-isomers were isolated. This was quite surprising because two series of $c i s-\left[\mathrm{PtCl}_{2}(\mathrm{~L})_{2}\right]$ complexes with differently substituted N6-benzyladenine derivatives [16] or with 7-azaindole derivatives [17] were formerly prepared by the same procedure, i.e., the reaction of $\mathrm{K}_{2}\left[\mathrm{PtCl}_{4}\right]$ with the corresponding $\mathrm{N}$-donor ligand. This unexpected behaviour may be connected with very low thermodynamic stability of the cis-isomers, which probably transform instantly into the trans-isomers. We tried to detect the cis-to-trans transformation process by means of ${ }^{195} \mathrm{Pt}$-NMR experiments, however, although the NMR spectra were measured immediately after the complex preparation, only the presence of pure trans-isomer was confirmed (see below for more details).

It has been found that the chlorination at the $\mathrm{C} 2$ atom on the purine moiety of the $\mathrm{L}_{\mathrm{n}}$ ligand is important for final complex solubility, and thus the complexes 10-13, which involve 2-chloro-N6benzyladenosine derivatives, are more soluble in DMF, ethanol, methanol and acetone than complexes 1-9, whose structures contain N6-benzyladenosines (see Scheme 1). A limited solubility in distilled water was observed for all the complexes. The obtained results of the elemental analysis for the prepared complexes are in good agreement with the calculated ones.

Scheme 1. Schematic representations of the N6-benzyladenosine-based N-donor ligands $\left(\mathbf{L}_{\mathbf{1}}-\mathbf{L}_{\mathbf{1 3}}\right)$ involved in structures of complexes 1-13.
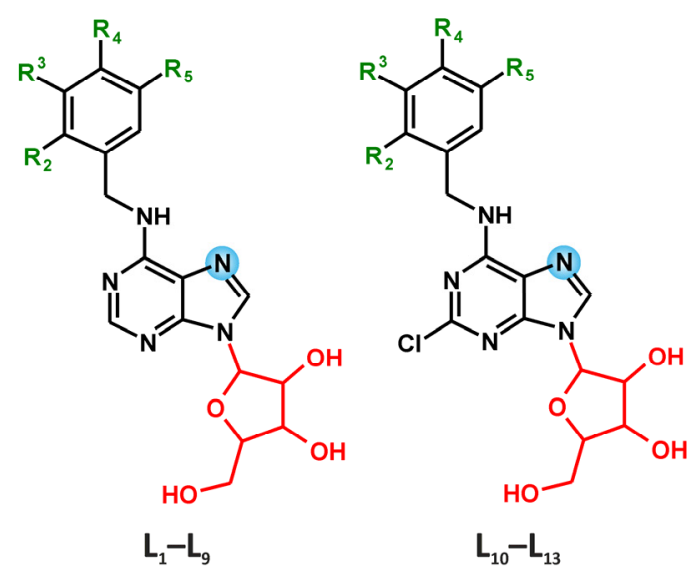

\begin{tabular}{lllll}
$\mathrm{L}_{n}$ (complex) & $\mathbf{R}_{2}$ & $\mathrm{R}_{3}$ & $\mathbf{R}_{4}$ & $\mathbf{R}_{5}$ \\
\hline $\mathrm{L}_{1}(\mathbf{1})$ & $\mathrm{OCH}_{3}$ & $\mathrm{H}$ & $\mathrm{H}$ & $\mathrm{H}$ \\
$\mathrm{L}_{2}(\mathbf{2})$ & $\mathrm{H}$ & $\mathrm{H}$ & $\mathrm{OCH}_{3}$ & $\mathrm{H}$ \\
$\mathrm{L}_{3}(\mathbf{3})$ & $\mathrm{Cl}$ & $\mathrm{H}$ & $\mathrm{H}$ & $\mathrm{H}$ \\
$\mathrm{L}_{4}(\mathbf{4})$ & $\mathrm{H}$ & $\mathrm{H}$ & $\mathrm{Cl}$ & $\mathrm{H}$ \\
$\mathrm{L}_{5}(\mathbf{5})$ & $\mathrm{OH}$ & $\mathrm{H}$ & $\mathrm{H}$ & $\mathrm{H}$ \\
$\mathrm{L}_{6}(\mathbf{6})$ & $\mathrm{H}$ & $\mathrm{OH}$ & $\mathrm{H}$ & $\mathrm{H}$ \\
$\mathrm{L}_{7}(\mathbf{7})$ & $\mathrm{OH}$ & $\mathrm{OCH}_{3}$ & $\mathrm{H}$ & $\mathrm{H}$ \\
$\mathrm{L}_{8}(\mathbf{8})$ & $\mathrm{H}$ & $\mathrm{H}$ & $\mathrm{F}$ & $\mathrm{H}$ \\
$\mathrm{L}_{9}(\mathbf{9})$ & $\mathrm{H}$ & $\mathrm{H}$ & $\mathrm{CH}_{3}$ & $\mathrm{H}$ \\
$\mathrm{L}_{10}(\mathbf{1 0})$ & $\mathrm{H}$ & $\mathrm{OH}$ & $\mathrm{H}$ & $\mathrm{H}$ \\
$\mathrm{L}_{11}(\mathbf{1 1})$ & $\mathrm{H}$ & $\mathrm{H}$ & $\mathrm{OH}$ & $\mathrm{H}$ \\
$\mathrm{L}_{12}(\mathbf{1 2})$ & $\mathrm{OH}$ & $\mathrm{OCH}$ & $\mathrm{H}$ & $\mathrm{H}$ \\
$\mathrm{L}_{13}(\mathbf{1 3})$ & $\mathrm{OH}$ & $\mathrm{H}$ & $\mathrm{H}$ & $\mathrm{CH}_{3}$ \\
\hline
\end{tabular}

All the complexes behave as non-electrolytes in DMF solutions (1.2-3.5 $\left.\mathrm{S} \cdot \mathrm{cm}^{2} \cdot \mathrm{mol}^{-1}\right)$ [18]. Thermal decomposition of 1-13 started right after the beginning of the experiment and is accompanied by a loss of the solvate molecules $\left(1 / 2 \mathrm{CH}_{3} \mathrm{OH}\right.$ for $1,5,8$ and $9, \mathrm{CH}_{3} \mathrm{OH}$ for $2,4,6,7,11$ and $12,1 / 2 \mathrm{H}_{2} \mathrm{O}$ for 3 and $3 / 4 \mathrm{CH}_{3} \mathrm{OH}$ for $\mathbf{1 0}$ and 13). The calculated weight losses of the desolvation process differ from the calculated ones by no more than $0.3 \%$. The desolvated complexes decay to PtO without the formation of any thermally stable intermediates from $100-186{ }^{\circ} \mathrm{C}$ to $476-595{ }^{\circ} \mathrm{C}$. 
The ESI- mass spectra of 1-13 dissolved in methanol were found to be similar in terms of the detected types of species (see Supplementary Material). The pseudomolecular peaks corresponding to $\left[\mathrm{PtCl}_{2}\left(\mathrm{~L}_{\mathrm{n}}\right)_{2}-\mathrm{H}\right]^{-}$were detected in the ESI- mass spectra of 1-13. Typically, the most intense peaks belonged to the $\left[\mathrm{PtCl}_{3}\left(\mathrm{~L}_{\mathrm{n}}\right)_{2}\right]^{-}$species. The species whose composition corresponded to the other detected peaks, involved the appropriate adenine derivative without ribose (symbolized as $\mathrm{L}_{\mathrm{n}}{ }^{\prime}$ ). Concretely $\left.\left[\mathrm{PtCl}_{2}\left(\mathrm{~L}_{\mathrm{n}}\right)\left(\mathrm{L}_{\mathrm{n}}{ }^{\prime}\right)-\mathrm{H}\right]^{-},{ }, \mathrm{PtCl}\left(\mathrm{L}_{\mathrm{n}}\right)\left(\mathrm{L}_{\mathrm{n}}{ }^{\prime}\right)-2 \mathrm{H}\right]^{-}$and $\left[\mathrm{PtCl}\left(\mathrm{L}_{\mathrm{n}}{ }^{\prime}\right)-2 \mathrm{H}\right]^{-}$were found in the spectra.

Detection of the characteristic bands of the appropriate N6-benzyladenosine derivatives $\left(\mathbf{L}_{\mathbf{1}}-\mathbf{L}_{\mathbf{1 3}} ;[19,20]\right)$ in the IR spectra of the complexes $\mathbf{1}-\mathbf{1 3}$ proved the presence of the mentioned organic ligands in the structure of the studied complexes. The bands were found and assigned as follows: the medium to strong bands at $3408-3584 \mathrm{~cm}^{-1}$ can be attributed to $v(\mathrm{O}-\mathrm{H})$ of the ribose moiety, the medium to strong bands between 3308 and $3359 \mathrm{~cm}^{-1}$ are assignable to $v(\mathrm{~N}-\mathrm{H})$ and the medium bands between 3121 and $3133 \mathrm{~cm}^{-1}$ belong to $v(\mathrm{C}-\mathrm{H})_{\mathrm{ar}}$. It should be pointed out that the interpretation of the bands in the region of $3100-3600 \mathrm{~cm}^{-1}$ is markedly influenced by overlapping of the vibrations. The majority of the bands found in the $660-900 \mathrm{~cm}^{-1}$ and $1450-1590 \mathrm{~cm}^{-1}$ region are assignable to the skeletal vibrations of the purine moiety, while the bands at $1605-1616 \mathrm{~cm}^{-1}$ can be attributed $v(\mathrm{C}=\mathrm{N})_{\text {ar }}$ purine skeletal vibrations [20]. The substitutions at the aromatic rings were proved by the presence of the stretching vibrations of $v(\mathrm{C}-\mathrm{Cl})_{\mathrm{ar}}(\mathbf{3}, \mathbf{4}, \mathbf{1 1}-\mathbf{1 3}), v(\mathrm{C}-\mathrm{F})_{\mathrm{ar}}(\mathbf{8})$ and $v(\mathrm{C}-\mathrm{O})_{\mathrm{ar}}(\mathbf{1}, \mathbf{2}$, 5-7, 11-13) in the regions of 1152-1182, at 1215, and 1214-1248 $\mathrm{cm}^{-1}$, respectively, in the IR spectra. The bands of medium to strong intensity at $1053-1116 \mathrm{~cm}^{-1}$ can be attributed to the $v(\mathrm{C}-\mathrm{O})_{\text {aliph }}$ vibrations, which belong to the hemiacetal groups of the ribose moiety. The bands between 326 and $349 \mathrm{~cm}^{-1}$ are assignable to $v(\mathrm{Pt}-\mathrm{Cl})$, while those detected between 510 and $545 \mathrm{~cm}^{-1}$ belong to $v(\mathrm{Pt}-\mathrm{N})$ [21]

The ${ }^{1} \mathrm{H}$-, ${ }^{13} \mathrm{C}$ - and ${ }^{15} \mathrm{~N}$-NMR signals of free N6-benzyladenosines $\mathbf{L}_{\mathbf{1}}-\mathbf{L}_{\mathbf{1 3}}$ were detected in the spectra of the complexes (except for $\mathrm{N} 3$ in 13). The ${ }^{1} \mathrm{H}-,{ }^{13} \mathrm{C}$ - and ${ }^{15} \mathrm{~N}-\mathrm{NMR}$ coordination shift values ( $\Delta \delta=\delta_{\text {complex }}-\delta_{\text {ligand }}$, ppm; see Table 1) clearly showed the N7-coordination mode of the $\mathbf{L}_{\mathbf{1}}-\mathbf{L}_{\mathbf{1 3}}$ molecules to the central $\mathrm{Pt}(\mathrm{II})$ atom, similarly as reported for the platinum(II) dichlorido complexes involving N9-substituted N6-benzyladenine (analogous NMR studies in combination with crystallography; [16]) or adenine [22] derivatives. The greatest coordination shifts in the ${ }^{1} \mathrm{H}-\mathrm{NMR}$ and ${ }^{13} \mathrm{C}$-NMR spectra were found for the atoms situated close to the coordination site represented by the $\mathrm{N} 7$ atom, i.e. $\mathrm{N6H}, \mathrm{C} 8 \mathrm{H}, \mathrm{C} 5$ and $\mathrm{C} 8$ (Table 1). The ${ }^{15} \mathrm{~N}$ signals found by ${ }^{1} \mathrm{H}-{ }^{15} \mathrm{~N}$ gs-HMBC experiments proved beyond all doubt the coordination via the $\mathrm{N} 7$ atom. It is obvious that the signals of the N7 atom are shifted much more as compared with other nitrogen atoms involved in the structure of the studied complexes (Table 1) that means the N1, N3, N6 and N9 atoms are not significantly influenced by the ligand coordination to $\mathrm{Pt}(\mathrm{II})$ atom. It is well known that conclusions about the isomer types can be obtained from ${ }^{195} \mathrm{Pt}-\mathrm{NMR}$ experiments, where significant differences between chemical shifts of $c i s-\left(\delta^{c i s}\right)$ and trans- $\left(\delta^{\text {trans }}\right)$ complexes are expected, as was already proved in our previous papers regarding NMR and crystallographic study of the cis-to-trans isomerisation of platinum(II) dichlorido complexes with differently substituted N6-benzyladenine derivatives, with $\delta^{c i s} \approx-2020 \mathrm{ppm}$ and $\delta^{\text {trans }} \approx-2065 \mathrm{ppm}[16]$. As can be seen from the chemical shifts listed in Table 1 and depicted in Figure 1, those ones assignable to trans-isomers 1-13 correlated well with the previously reported values. Moreover, the number, position and intensity of the signals detected in the ${ }^{195} \mathrm{Pt}-\mathrm{NMR}$ spectra of 1-13 did not change in time (up to eight weeks), which is typical feature of trans-isomers of platinum(II) dichlorido complexes, while being highly improbable for the cis-isomers. 
Figure 1. ${ }^{195} \mathrm{Pt}$-NMR spectra of the selected complexes $\mathbf{4}$ and $\mathbf{8}$ (involving N6-benzyladenosine derivatives) and $\mathbf{1 0}$ and $\mathbf{1 2}$ (involving 2-chloro-N6-benzyladenosine derivatives).

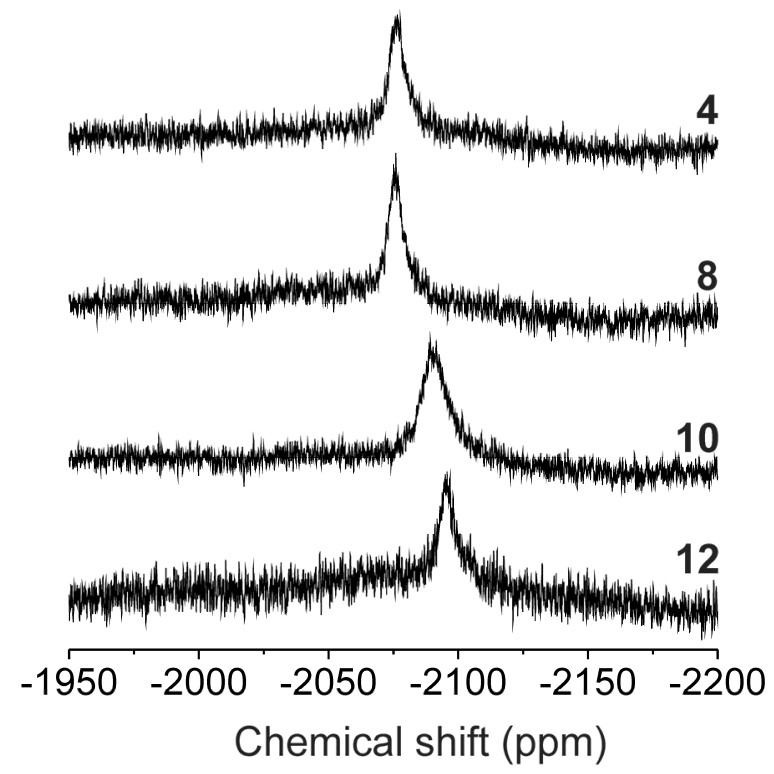

Table 1. The ${ }^{1} \mathrm{H}-,{ }^{13} \mathrm{C}$ - and ${ }^{15} \mathrm{~N}-\mathrm{NMR}$ coordination shifts $\left(\Delta \delta=\delta_{\text {complex }}-\delta_{\text {ligand }} ; \mathrm{ppm}\right)$ of the selected atoms and ${ }^{195} \mathrm{Pt}$ chemical shifts $(\delta$; ppm) of the prepared complexes.

\begin{tabular}{|c|c|c|c|c|c|c|c|c|c|c|c|c|c|c|}
\hline & \multicolumn{3}{|c|}{${ }^{1}$ H-NMR } & \multicolumn{5}{|c|}{${ }^{13} \mathrm{C}-\mathrm{NMR}$} & \multicolumn{5}{|c|}{${ }^{15} \mathrm{~N}-\mathrm{NMR}$} & \multirow[t]{2}{*}{05} \\
\hline & $\mathrm{C2H}$ & N6H & $\mathrm{C8H}$ & $\mathrm{C} 2$ & $\mathrm{C} 4$ & C5 & C6 & C8 & N1 & N3 & N6 & N7 & N9 & \\
\hline 1 & -0.09 & 0.82 & 0.84 & 1.35 & -0.82 & -4.07 & -2.36 & 2.76 & 3.82 & 1.17 & 8.47 & -105.03 & 5.60 & -2077.10 \\
\hline 2 & 0.18 & 0.52 & 0.84 & 1.41 & -0.85 & -4.03 & -2.28 & 2.92 & 5.03 & 2.00 & 6.67 & -105 & 6.17 & \\
\hline 3 & 0.17 & 0.60 & 0.88 & & -0.80 & -4. & & 2.96 & 3.24 & 0.82 & 6.57 & & 4.96 & \\
\hline 4 & 0.19 & 0.51 & 0.92 & 1.27 & -0.98 & -4.14 & -2.37 & 2.88 & 3.61 & 1.55 & 4.96 & -106 & 5.45 & -2071.38 \\
\hline 5 & 0.12 & 0.69 & 0.7 & 1.61 & -0.82 & -3.9 & -1 & 2.62 & & 0.70 & 5.05 & & 5.09 & \\
\hline 6 & 0.18 & 0.59 & 0.84 & 1.31 & -0.88 & -4.07 & -2.29 & 2.93 & 3.85 & 1.91 & 5.51 & -10 & 6.21 & -2074.68 \\
\hline 7 & 0.15 & 0.75 & 0.69 & 1.49 & -0.92 & -3.97 & -4.06 & 2.73 & 6.98 & 0.34 & 5.82 & -106.22 & 4.78 & -2078.30 \\
\hline 8 & 0.19 & 0.52 & 0.9 & 1.31 & -0.93 & -4.13 & -2.29 & & 3.67 & 0.33 & 6.52 & -10 & 6.32 & -2071.68 \\
\hline 9 & 0.19 & 0.55 & 0.83 & 1.34 & -0.88 & -4.07 & -2.32 & 2.89 & 4.46 & 1.76 & 4.89 & -106.10 & 5.86 & -2073.15 \\
\hline 10 & - & 0.26 & 0.83 & -0.53 & -1.19 & -3.76 & -0.66 & 3.03 & 3.13 & -0.31 & 6.15 & -106.52 & 5.02 & -2084.94 \\
\hline 11 & - & 0.60 & 0.83 & 1.30 & -1.01 & -3.68 & -2.18 & 3.14 & 3.45 & 0.26 & 3.30 & -106.24 & 5.00 & -2083.47 \\
\hline 12 & - & 0.81 & 0.69 & 1.34 & -0.90 & -3.66 & -2.31 & 3.04 & 3.92 & 0.16 & 4.90 & -105.72 & 5.03 & -2088.28 \\
\hline 13 & - & 0.85 & 0.78 & 0.12 & -0.83 & -3.27 & -0.60 & 1.81 & 4.89 & - & 4.96 & -105.76 & 5.33 & -2091.62 \\
\hline
\end{tabular}

\subsection{In Vitro Cytotoxic Activity}

The trans-complexes 1-13 were screened for their in vitro antitumor effect against two human cancer cell lines, namely breast adenocarcinoma (MCF7) and osteosarcoma (HOS). We also tested $\mathrm{K}_{2}\left[\mathrm{PtCl}_{4}\right]$ and cisplatin to compare potential antitumor activity of the prepared complexes with the precursors and with commercially used platinum-based drug (N6-benzyladenosine derivatives involved in the structures of 1-13 were not tested, since their in vitro antitumor activity against HOS and MCF7 was previously reported [12]). Unfortunately, although the complexes 1-13 were found to be well soluble $(>50.0 \mu \mathrm{M})$ in the medium used $(0.1 \%$ DMF in distilled water), in other words they 
should be quite bioavailable, they did not show any cytotoxic effects up to the highest concentration tested $\left(50.0 \mu \mathrm{M}\right.$ concentration, $\left.\mathrm{IC}_{50}>50.0 \mu \mathrm{M}\right)$. As for $\mathrm{K}_{2}\left[\mathrm{PtCl}_{4}\right]$ it was found to be inactive up to 50.0 $\mu \mathrm{M}$. The $\mathrm{IC}_{50}$ values determined for cisplatin equal $18.1 \pm 5.1 \mu \mathrm{M}$ (MCF7) and 25.4 $\pm 8.5 \mu \mathrm{M}$ (HOS).

Although the results of in vitro antitumor activity of 1-13 against HOS and MCF7 do not seem promising, it should be noted that situation regarding the free ligands $L_{n}$ is completely different as shown in a Czech patent [12], where it is demonstrated that some of the ligands $\mathbf{L}_{\mathbf{1}}-\mathbf{L}_{\mathbf{1 2}}\left(\mathbf{L}_{\mathbf{1 3}}\right.$ was not reported) are moderately to highly effective against $\operatorname{HOS}\left(\mathrm{IC}_{50}=2.8 \mu \mathrm{M}\right.$ for $\mathbf{L}_{\mathbf{5}}, 20.0 \mu \mathrm{M}$ for $\mathbf{L}_{\mathbf{8}}, 21.2$ $\mu \mathrm{M}$ for $\mathbf{L}_{\mathbf{1}},>166.7 \mu \mathrm{M}$ for $\mathbf{L}_{\mathbf{2}-4,6,7,9-12}$ ), MCF7 $\left(\mathrm{IC}_{50}=11.4 \mu \mathrm{M}\right.$ for $\mathbf{L}_{\mathbf{5}}, 14.0 \mu \mathrm{M}$ for $\mathbf{L}_{\mathbf{8}}, 23.0 \mu \mathrm{M}$ for $\mathbf{L}_{12}, 27.0 \mu \mathrm{M}$ for $\mathbf{L}_{7},>166.7 \mu \mathrm{M}$ for $\mathbf{L}_{\mathbf{1 - 4 , 6 9 - 1 1}}$ ), and human T-lymphoblastic $\left(\mathrm{CEM}\right.$; $\mathrm{IC}_{50}=3.2 \mu \mathrm{M}$ for $\mathbf{L}_{1}, 14.5 \mu \mathrm{M}$ for $\mathbf{L}_{3}, 10.2 \mu \mathrm{M}$ for $\mathbf{L}_{\mathbf{4}}, 0.7 \mu \mathrm{M}$ for $\mathbf{L}_{5}, 51.9 \mu \mathrm{M}$ for $\mathbf{L}_{\mathbf{6}}, 0.3 \mu \mathrm{M}$ for $\mathbf{L}_{7}, 1.3 \mu \mathrm{M}$ for $\mathbf{L}_{\mathbf{8}}$, $47.8 \mu \mathrm{M}$ for $\mathbf{L}_{\mathbf{1 0}}, 39.7 \mu \mathrm{M}$ for $\mathbf{L}_{\mathbf{1 1}}, 0.2 \mu \mathrm{M}$ for $\mathbf{L}_{\mathbf{1 2}}$ ) and promyelocytic (HL-60; $\mathrm{IC}_{50}=2.3 \mu \mathrm{M}$ for $\mathbf{L}_{\mathbf{1}}$, $1.6 \mu \mathrm{M}$ for $\mathbf{L}_{3}, 1.7 \mu \mathrm{M}$ for $\mathbf{L}_{4}, 0.4 \mu \mathrm{M}$ for $\mathbf{L}_{5}, 23.7 \mu \mathrm{M}$ for $\mathbf{L}_{6}, 0.2 \mu \mathrm{M}$ for $\mathbf{L}_{7}, 1.2 \mu \mathrm{M}$ for $\mathbf{L}_{\mathbf{8}}, 15.9 \mu \mathrm{M}$ for $\mathbf{L}_{\mathbf{1 0}}, 9.5 \mu \mathrm{M}$ for $\mathbf{L}_{\mathbf{1 1}}, 0.1 \mu \mathrm{M}$ for $\mathbf{L}_{12}$ ) leukemic cell lines. As already mentioned in the Introduction, one of the main reasons for the present study was to utilize these organic molecules as $\mathrm{N}$-donor ligands in platinum(II) complexes and find out whether the complex formation may influence the resulting cytotoxic effect of the prepared complexes. Therefore, two human cancer cell lines (HOS and MCF7) were chosen for a biological screening. Unfortunately, it has been found that incorporation of the N6-benzyladenosine derivatives $\mathbf{L}_{\mathbf{1}}-\mathbf{L}_{\mathbf{1 3}}$ into trans-platinum(II) dichlorido complexes 1-13 did not produce the expected goal. However, it is possible that the prepared complexes may show a selective cytotoxicity against human cancer cell lines and thus, next time-consuming experiments on diverse types of human cancer cell lines will be necessary to prove this presumption. Anyway, it is also known that initially inactive platinum complexes may serve as pro-drugs [23,24] owing to their metabolic activation, e.g. by interactions with diverse biomolecules such as reducing amino acids or proteins.

\subsection{Interactions of the Selected Complexes $\mathbf{7}$ and $\mathbf{1 2}$ with L-Methionine, Evaluated by}

\section{Mass Spectrometry}

In an effort to identify the actual active species which might be biologically relevant in terms of long-lasting biological activity (due to anticipated slow kinetics of $\mathrm{L}_{\mathrm{n}}-\mathbf{P t}(\mathbf{I I})-\mathbf{S}-$ Met interaction) and to mechanistically describe the basic modes of interactions of two representative complexes $\mathbf{7}$ and $\mathbf{1 2}$ with relevant sulfur-containing biomolecule (L-methionine), the electrospray-ionization mass-spectrometry (ESI-MS) experiments were carried out in both negative and positive ionization modes. To simulate at least one aspect of the physiological conditions, the solution of L-methionine was used containing the physiological levels $(20 \mu \mathrm{M})$ of this significant sulfur-containing biomolecule [25].

The corresponding interaction systems were formed by mixing the two freshly prepared working solutions: (solution 1) containing L-methionine (at the final concentration of $20 \mu \mathrm{M}$ ) and (solution 2) containing the solutions of 7 or $\mathbf{1 2}$ in methanol, to give the final concentration of $10 \mu \mathrm{M}$ (the final ratio of $\mathrm{H}_{2} \mathrm{O}: \mathrm{MeOH}$ was $1: 1 \mathrm{v} / \mathrm{v}$ ). The resulting interacting solutions were measured immediately after the preparation and $12 \mathrm{~h}$ after preparation either. The interacting systems stayed clear during the whole $12 \mathrm{~h}$ of the observation.

The ESI-MS experiments revealed a relatively simple 1:1 exchange mechanism (one $\mathrm{L}_{\mathrm{n}}$ molecule was replaced by one L-methionine molecule) in the measured interacting systems (Figure 2). In the 
control samples, composed only by the solutions of the complexes 7, and 12, respectively, the following main ions were identified in the negative ionization mode for $\mathbf{1 2}$ (see Figure 2a), top spectrum; $\mathrm{m} / \mathrm{z}$, [the corresponding pseudomolecular ion] ${ }^{-}$, sorted by the decreasing relative abundance]: 1175.19, $\left[\mathrm{PtCl}_{3}\left(\mathrm{~L}_{12}\right)_{2}\right]^{-} ; 1140.04,\left[\mathrm{PtCl}_{2}\left(\mathrm{~L}_{12}\right)_{2}-\mathrm{H}\right]^{-} ; 435.95,\left[\mathrm{~L}_{12}-\mathrm{H}\right]^{-}$; and in positive ionization mode for 7 (see Figure $2 \mathrm{~b}$ ), top spectrum; $\mathrm{m} / \mathrm{z}$, [the corresponding pseudomolecular ion] ${ }^{+}$, sorted by the decreasing relative abundance]: 404.28, $\left[\mathrm{L}_{7}+\mathrm{H}\right]^{+} ; 1111.03,\left[\mathrm{PtCl}_{2}\left(\mathrm{~L}_{7}\right)_{2}+\mathrm{K}\right]^{+} ; 1073.01$, $\left[\mathrm{PtCl}_{2}\left(\mathrm{~L}_{7}\right)_{2}+\mathrm{H}\right]^{+} ; 1092.85,\left[\mathrm{PtCl}_{2}\left(\mathrm{~L}_{7}\right)_{2}+\mathrm{H}+\mathrm{H}_{2} \mathrm{O}\right]^{+}$. An analogous set of pseudomolecular ions, as presented in Figure 2, was identified in the corresponding mass spectra of 7 measured in the negative ionization mode and $\mathbf{1 2}$ measured in the positive ionization mode (Figure S1). No significant qualitative differences, apart from the appearance of pseudomolecular ions (see Figure 2a), middle spectrum; $m / z$, [the corresponding pseudomolecular ion] $\left.{ }^{-}\right]: 148.03$ [(L-Met)-H] ${ }^{-}$; and Figure 2b, middle spectrum; $m / z$, [the corresponding pseudomolecular ion $\left.]^{+}\right): 150.02[(\mathrm{~L}-\mathrm{Met})+\mathrm{H}]^{+}$corresponding to the presence of L-methionine in the interacting systems, were observed in the measured mass spectra just after mixing the solutions of $\mathbf{7}$ and $\mathbf{1 2}$ with L-methionine in both the negative and positive modes of electrospray-ionization.

In accordance with the established slower kinetics of interactions between the dichloridoplatinum(II) complexes involving the $\mathrm{N}$-donor co-ligands and methionine [26], we identified the significant changes in both qualitative and quantitative aspects of the mass spectra of the interacting systems measured $12 \mathrm{~h}$ after the mixing of their principal components. The mass spectra measured in both ionization modes (see Figures 2a,b), lower spectra, proved the formation of the analogous coordination species - see Figure 2a, lower spectrum; $\mathrm{m} / \mathrm{z}$, [the corresponding pseudomolecular ion] ${ }^{\top}$ ): $851.00\left[\mathrm{PtCl}_{2}\left(\mathrm{~L}_{12}\right)(\mathrm{L}-\mathrm{Met})-\mathrm{H}\right]^{-}$; and Figure $2 \mathrm{~b}$, lower spectrum; $m / z$, [the corresponding pseudomolecular

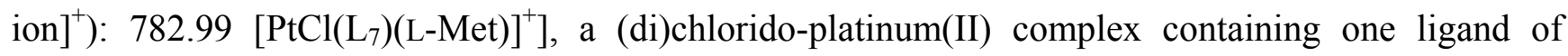
adenosine derivative and one L-methionine ligand in its coordination sphere. The corresponding cleavage of one adenosine ligand from $\mathbf{7}$, and 12, respectively, manifested itself quantitatively by the increased ratio between the relative abundance of pseudomolecular ions of the free adenosine ligands and the relative abundance of pseudomolecular ions of $\mathbf{7}$ or $\mathbf{1 2 .}$

As some of the transplatin derived complexes involving the sulfur-containing ligands proved their remarkable cytotoxic effects [27], the obtained results of interaction studies suggest that the slow kinetics of the ligand exchange between the studied complexes and sulfur-containing biomolecules might represent the essential step for their bio-activation, thus offering the explanation for the insignificant cytotoxicity found by the standardized screening models and opening the new horizons for them to be studied more deeply by means of advanced biological models, which would further consider them as pro-drugs. 
Figure 2. (a) The ESI- mass spectra of 12 (top spectrum), and interacting systems with Lmethionine measured immediately after the preparation (middle spectrum) and $12 \mathrm{~h}$ after the preparation (lower spectrum); (b) the ESI+ mass spectra of 7 (top spectrum), and interacting systems with L-methionine measured immediately after the preparation (middle spectrum) and $12 \mathrm{~h}$ after the preparation (lower spectrum).

(a)

Negative ionization mode
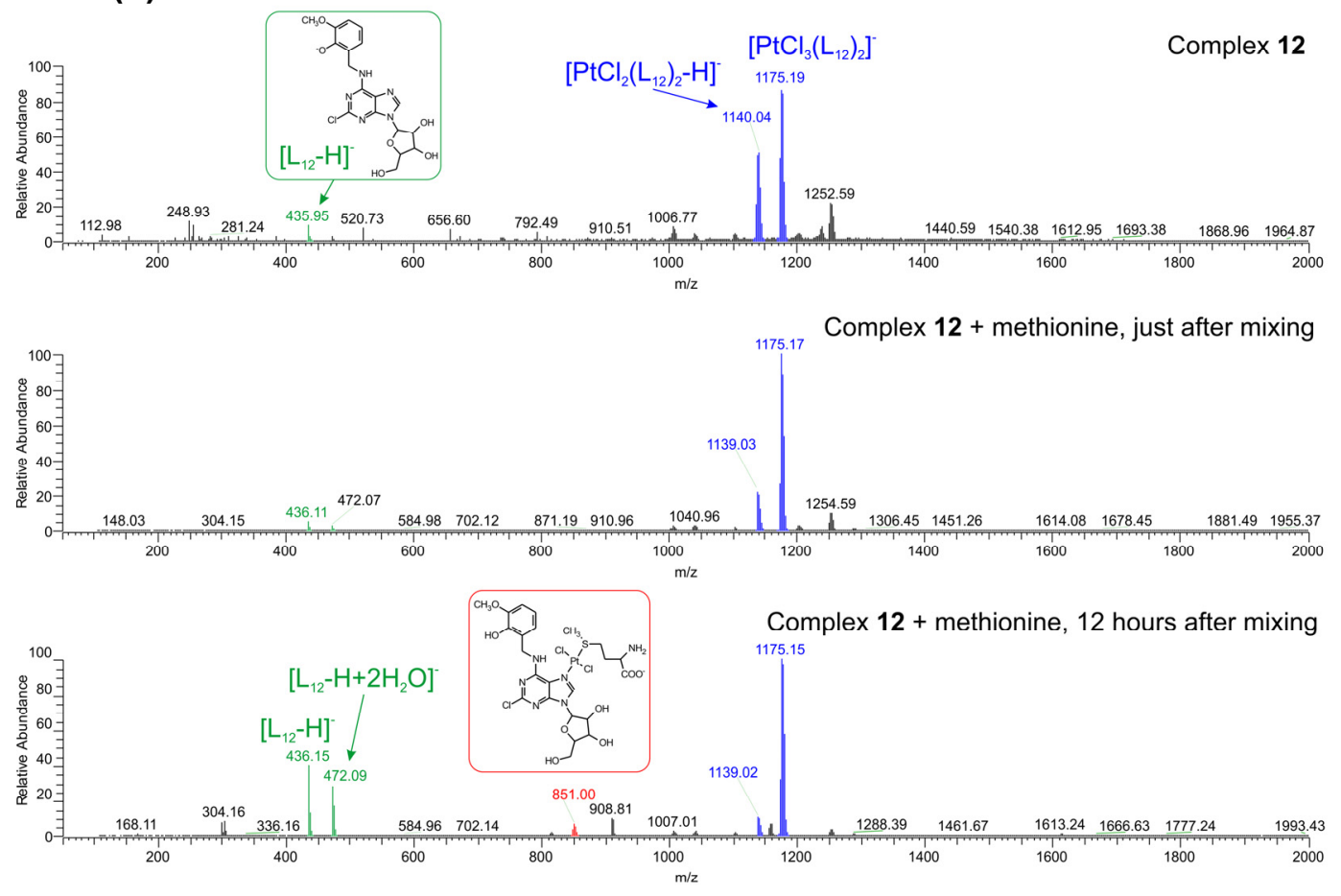

(b)

Positive ionization mode
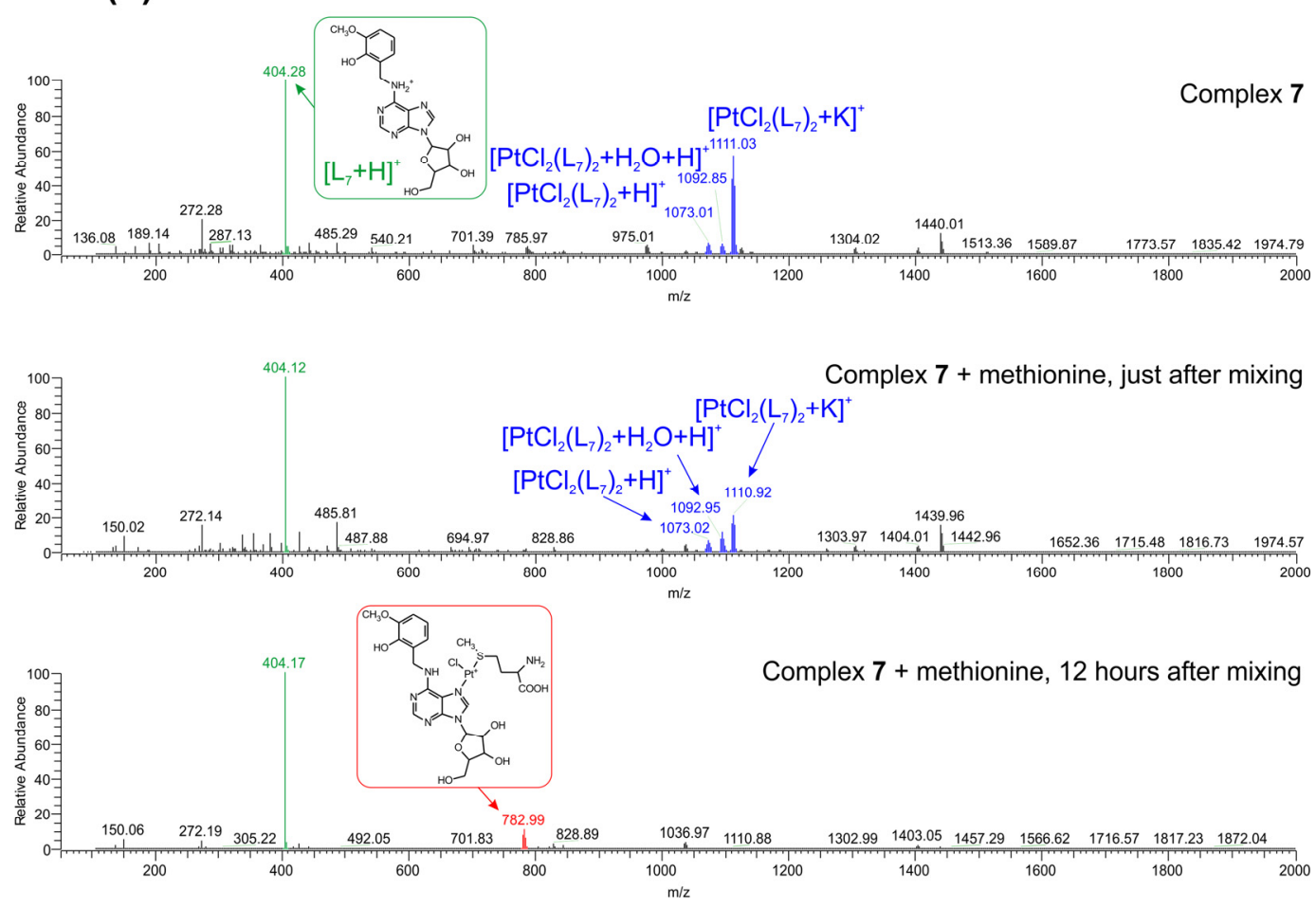


\section{Experimental}

\subsection{Materials}

$\mathrm{K}_{2}\left[\mathrm{PtCl}_{4}\right]$, 6-chloropurine-9-riboside, 2,6-dichloropurine-9-riboside, 2-methoxybenzylamine, 3methoxybenzylamine, 4-methoxybenzylamine, 2,3-dimethoxybenzylamine, 2,5-dimethoxybenzylamine, 2-chlorobenzylamine, 4-chlorobenzylamine, 4-fluorobenzylamine, 4-methylbenzylamine, triethylamine and solvents used were purchased from Sigma-Aldrich Co. (Prague, Czech Republic), Acros Organics Co. (Pardubice, Czech Republic), Lachema Co. (Brno, Czech Republic) and Fluka Co. (Prague, Czech Republic) and used without further purification. 2-hydroxybenzylamine, 3-hydroxybenzylamine, 4-hydroxybenzylamine, 2-hydroxy-3-methoxybenzylamine and 2-hydroxy-5-methylbenzylamine were obtained from the respective methoxy derivatives by the action of the concentrated $\mathrm{HBr}$ or $\mathrm{HI}$ acids in the presence of acetylacetate.

\subsection{Methods}

Elemental analysis (C, H, N) was performed on a Flash 2000 CHNS Elemental Analyzer (Thermo Scientific, Waltham, MA, USA). Conductivity measurements of $10^{-3} \mathrm{M}$ DMF solutions of the prepared complexes were carried out using a conductometer $340 \mathrm{i} / \mathrm{SET}$ (WTW) at $25^{\circ} \mathrm{C}$. Simultaneous thermogravimetry (TG) and differential thermal (DTA) analysis was carried out using an Exstar TG/DTA 6200 thermal analyzer (Seiko Instruments Inc., Torrance, CA, USA); dynamic air atmosphere $\left(100 \mathrm{~mL} \mathrm{~min}^{-1}\right), 25-900{ }^{\circ} \mathrm{C}\left(5.0^{\circ} \mathrm{C} \mathrm{min}^{-1}\right)$. Infrared spectra $\left(150-600 \mathrm{~cm}^{-1}\right.$ region by nujol technique and $400-4,000 \mathrm{~cm}^{-1}$ region by ATR technique) were recorded on a Nexus 670 FT-IR (Thermo Nicolet, Waltham, MA, USA). ${ }^{1} \mathrm{H},{ }^{13} \mathrm{C}$ and ${ }^{195} \mathrm{Pt}$ NMR spectra and 2D correlation experiments $\left({ }^{1} \mathrm{H}-{ }^{1} \mathrm{H}\right.$ gs-COSY, ${ }^{1} \mathrm{H}-{ }^{1} \mathrm{H}$ gs-ROESY, ${ }^{1} \mathrm{H}-{ }^{13} \mathrm{C}$ gs-HMQC, ${ }^{1} \mathrm{H}-{ }^{13} \mathrm{C}$ gs-HMBC and ${ }^{1} \mathrm{H}-{ }^{15} \mathrm{~N}$ gs-HMBC; gs $=$ gradient selected, $\mathrm{COSY}=$ correlation spectroscopy, ROESY = rotating frame Overhauser effect spectroscopy, HMQC = heteronuclear multiple quantum coherence and $\mathrm{HMBC}=$ heteronuclear multiple bond coherence) of the DMF- $\mathrm{d}_{7}$ solutions were measured at $300 \mathrm{~K}$ on a Varian 400 device (Varian, Santa Clara, CA, USA) at $400.00 \mathrm{MHz}\left({ }^{1} \mathrm{H}\right), 100.58 \mathrm{MHz}\left({ }^{13} \mathrm{C}\right), 40.53 \mathrm{MHz}\left({ }^{15} \mathrm{~N}\right)$ and 85.78 $\mathrm{MHz}\left({ }^{195} \mathrm{Pt}\right) .{ }^{1} \mathrm{H}$ and ${ }^{13} \mathrm{C}$ spectra were adjusted against the tetramethylsilane $\left(\mathrm{Me}_{4} \mathrm{Si}\right)$ signals. ${ }^{195} \mathrm{Pt}$ spectra were calibrated against $\mathrm{K}_{2}\left[\mathrm{PtCl}_{6}\right]$ in $\mathrm{D}_{2} \mathrm{O}(0 \mathrm{ppm}) .{ }^{1} \mathrm{H}-{ }^{15} \mathrm{~N}$ gs-HMBC experiments were obtained at natural abundance and calibrated against the residual signals of the DMF adjusted to $8.03 \mathrm{ppm}\left({ }^{1} \mathrm{H}\right)$ and $104.7 \mathrm{ppm}\left({ }^{15} \mathrm{~N}\right)$. Splitting of the proton resonances is defined as $\mathrm{s}=$ singlet, $\mathrm{d}=$ doublet, $\mathrm{t}=$ triplet, $\mathrm{sx}=$ sextuplet, $\mathrm{sep}=$ septuplet, $\mathrm{br}=$ broad band, $\mathrm{dd}=$ doublet of doublets, $\mathrm{tt}=$ triplet of triplets, $\mathrm{m}=$ multiplet. ESI- mass spectra (methanol solutions) were obtained by an LCQ Fleet Ion Trap mass spectrometer (Thermo Scientific; QualBrowser software, version 2.0.7, Waltham, MA, USA).

\subsection{Synthesis}

N6-(2-methoxybenzyl)adenosine ( $\left.\mathbf{L}_{\mathbf{1}}\right)$, N6-(4-methoxybenzyl)adenosine ( $\left.\mathbf{L}_{\mathbf{2}}\right)$, N6-(2-chlorobenzyl)-

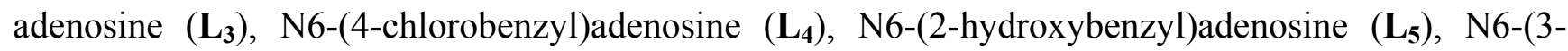
hydroxybenzyl)adenosine ( $\left.\mathbf{L}_{6}\right)$, N6-(2-hydroxy-3-methoxybenzyl)adenosine $\quad\left(\mathbf{L}_{7}\right)$, N6-(4-fluorobenzyl)adenosine ( $\left.\mathbf{L}_{\mathbf{8}}\right)$, N6-(4-methylbenzyl)adenosine (L9), 2-chloro-N6-(3-hydroxybenzyl)adenosine 
$\left(\mathbf{L}_{10}\right)$, 2-chloro-N6-(4-hydroxybenzyl)adenosine ( $\left.\mathbf{L}_{11}\right)$, 2-chloro-N6-(2-hydroxy-3-methoxybenzyl)adenosine $\left(\mathbf{L}_{\mathbf{1 2}}\right)$ and 2-chloro-N6-(2-hydroxy-5-methylbenzyl)adenosine $\left(\mathbf{L}_{13}\right)$ (see Scheme 1) were synthesized according to the general procedure, which involves the interaction of appropriate purinebased precursor with an excess of amine in an excess of triethylamine [28]. In our case, $1 \mathrm{mmol}$ of 6-chloropurine-9-riboside (for N6-benzyladenosine derivatives $\mathbf{L}_{\mathbf{1}}-\mathbf{L}_{\mathbf{9}}$ ) or 2,6-dichloropurine-9-riboside (for 2-chloro-N6-benzyladenosine derivatives $\mathbf{L}_{\mathbf{1 0}}-\mathbf{L}_{\mathbf{1 3}}$ ) reacted with $1.33 \mathrm{mmol}$ of the appropriate benzylamine derivative in $n$-butanol $(20 \mathrm{~mL})$ containing triethylamine $(1.67 \mathrm{mmol})$. The reaction mixture was stirred at $90{ }^{\circ} \mathrm{C}$ for $4 \mathrm{~h}$ and then it was left at $-5{ }^{\circ} \mathrm{C}$ in the freezer overnight. The white solid was collected by filtration and washed with cold $n$-butanol $(2 \times 5 \mathrm{~mL})$, cold distilled water $(2 \times 5 \mathrm{~mL})$ and diethyl ether $(2 \times 5 \mathrm{~mL})$. In case that not sufficient purity of the sample was achieved (controlled by thin-layer chromatography and elemental analysis), the product was recrystallized from ethanol. The results of elemental analyses, IR and NMR spectroscopy can be found in the Supplementary Material.

The solution $1.0 \mathrm{mmol}$ of $\mathbf{L}_{1}-\mathbf{L}_{13}$ in $50 \mathrm{~mL}$ of methanol was slowly poured in the solution of $0.5 \mathrm{mmol} \mathrm{K}_{2}\left[\mathrm{PtCl}_{4}\right]$ in a minimum volume of distilled water. The reaction mixture was stirred at room temperature for several days, followed by filtration of the obtained precipitate. The products of the composition trans- $\left[\mathrm{PtCl}_{2}\left(\mathrm{~L}_{1}\right)_{2}\right] \cdot 1 / 2 \mathrm{CH}_{3} \mathrm{OH}(\mathbf{1})$, trans $-\left[\mathrm{PtCl}_{2}\left(\mathrm{~L}_{2}\right)_{2}\right] \cdot \mathrm{CH}_{3} \mathrm{OH}(2)$, trans- $\left[\mathrm{PtCl}_{2}\left(\mathrm{~L}_{3}\right)_{2}\right] \cdot 1 / 2 \mathrm{H}_{2} \mathrm{O}$ (3), trans- $\left[\mathrm{PtCl}_{2}\left(\mathrm{~L}_{4}\right)_{2}\right] \cdot \mathrm{CH}_{3} \mathrm{OH}$ (4), trans- $\left[\mathrm{PtCl}_{2}\left(\mathrm{~L}_{5}\right)_{2}\right] \cdot \frac{1}{2} \mathrm{CH}_{3} \mathrm{OH}(5)$, trans- $\left[\mathrm{PtCl}_{2}\left(\mathrm{~L}_{6}\right)_{2}\right] \cdot \mathrm{CH}_{3} \mathrm{OH}$ (6), trans- $\left[\mathrm{PtCl}_{2}\left(\mathrm{~L}_{7}\right)_{2}\right] \cdot \mathrm{CH}_{3} \mathrm{OH}$ (7), trans- $\left[\mathrm{PtCl}_{2}\left(\mathrm{~L}_{8}\right)_{2}\right] \cdot \frac{1}{2} \mathrm{CH}_{3} \mathrm{OH} \quad(8)$, trans $-\left[\mathrm{PtCl}_{2}\left(\mathrm{~L}_{9}\right)_{2}\right] \cdot 1 / 2 \mathrm{CH}_{3} \mathrm{OH}$ (9), trans- $\left[\mathrm{PtCl}_{2}\left(\mathrm{~L}_{10}\right)_{2}\right] \cdot 3 / 4 \mathrm{CH}_{3} \mathrm{OH}(\mathbf{1 0})$, trans- $\left[\mathrm{PtCl}_{2}\left(\mathrm{~L}_{11}\right)_{2}\right] \cdot \mathrm{CH}_{3} \mathrm{OH}(\mathbf{1 1})$, trans $-\left[\mathrm{PtCl}_{2}\left(\mathrm{~L}_{12}\right)_{2}\right] \cdot \mathrm{CH}_{3} \mathrm{OH}(\mathbf{1 2})$ and trans- $\left[\mathrm{PtCl}_{2}\left(\mathrm{~L}_{13}\right)_{2}\right] \cdot 3 / 4 \mathrm{CH}_{3} \mathrm{OH} \quad(\mathbf{1 3})$, generally expressed as trans- $\left[\mathrm{PtCl}_{2}\left(\mathrm{~L}_{\mathrm{n}}\right)_{2}\right] \cdot x \operatorname{Solv} \quad \mathbf{1}-\mathbf{1 3}$ (Solv $=\mathrm{H}_{2} \mathrm{O}$ or $\mathrm{CH}_{3} \mathrm{OH}$ ), were washed by distilled water, methanol and diethyl ether and dried in desiccator over $\mathrm{KOH}$. The physical measurement results are given in the Supplementary Material.

\subsection{In Vitro Cytotoxic Activity Testing}

In vitro cytotoxicity was studied by an MTT assay [MTT $=3$-(4,5-dimethylthiazol-2-yl)-2,5diphenyltetrazolium bromide] against osteosarcoma (HOS; ECACC No. 87070202) and breast adenocarcinoma (MCF7; ECACC No. 86012803) human cancer cell lines supplied from European Collection of Cell Cultures (ECACC). The cell lines were cultured according to the ECACC instructions, maintained at $37{ }^{\circ} \mathrm{C}$ and $5 \% \mathrm{CO}_{2}$ in a humidified incubator (100\% humidity). The studied complexes 1-13, $\mathrm{K}_{2}\left[\mathrm{PtCl}_{4}\right]$, and cisplatin $(0.01,0.1,1.0,5.0,25.0$ and $50.0 \mu \mathrm{M}$ concentration), as well as vehicle (DMF, $0.1 \%, \mathrm{v} / \mathrm{v}$; positive control to assess the minimal cell damage, i.e., 100\% viability) and Triton $\mathrm{X}-100(1 \%, \mathrm{v} / \mathrm{v}$; negative control to assess the maximal cell damage, i.e., $0 \%$ viability) were added to the cell suspensions in 96-well culture plates and incubated for $24 \mathrm{~h}$. The MTT assay was measured spectrophotometrically at $540 \mathrm{~nm}$ (TECAN, Schoeller Instruments LLC, Prague, Czech Republic). The data from the respective cancer cells were acquired from three independent experiments (conducted in triplicate) using cells from different passages. The resulting $\mathrm{IC}_{50}$ values $(\mu \mathrm{M})$ were calculated from viability curves and the results are presented as arithmetic mean $\pm \mathrm{SD}$. 


\subsection{Interactions of the Selected Complexes $\mathbf{7}$ and 12 with L-Methionine, Evaluated by} Mass Spectrometry

The electrospray-ionization mass spectrometry (ESI-MS) is widely used method for studies of covalent [29] or non-covalent interactions ([30,31] and references therein) of small molecules or ions with biologically relevant molecules. Therefore, we performed the interaction experiments between the two complexes (7 and 12), one selected from the group of 2-chloro-substituted derivatives and the second one selected from the 2-unsubstituted group of compounds (dissolved in methanol, at the final concentration of $10 \mu \mathrm{M}$ ) with the physiological concentration of L-methionine (dissolved in water, at the final concentration of $20 \mu \mathrm{M}$ ), using an LCQ Fleet Ion Trap mass spectrometer, in both the negative and positive ionization modes. The measured solutions were infused directly to the spray-needle by linear pump with the rate of $50 \mu \mathrm{L} / \mathrm{min}$, and the measured range of ions was set from $\mathrm{m} / \mathrm{z} 50$ to 1500 . No additional tuning was needed to perform the analyses.

\section{Conclusions}

We prepared and thoroughly characterized thirteen platinum(II) dichlorido complexes of the general composition trans-[ $\left.\mathrm{PtCl}_{2}\left(\mathrm{~L}_{\mathrm{n}}\right)_{2}\right] \cdot x \mathrm{Solv}$ 1-13 (Solv $=$ water or methanol), which represent the first examples of the platinum complexes with N6-benzyladenosine derivatives acting as $\mathrm{N}$-donor ligands. The composition and constitution of the complexes were proved by the multinuclear $\left({ }^{1} \mathrm{H}-,{ }^{13} \mathrm{C}-,{ }^{195} \mathrm{Pt}\right.$ and ${ }^{15} \mathrm{~N}-$ ) and two-dimensional NMR spectroscopy. The screening of antitumor activity showed that the complexes 1-13 are inactive against the MCF7 and HOS human cancer cell lines $\left(\mathrm{IC}_{50}>50.0 \mu \mathrm{M}\right)$. The selected complexes $\mathbf{7}$ and $\mathbf{1 2}$ showed their ability to interact with the physiological levels of sulfur-containing biogenic biomolecule (L-methionine) by a relatively simple 1:1 exchange mechanism (one $\mathrm{L}_{\mathrm{n}}$ molecule was replaced by one L-methionine molecule), thus forming a mixed-nitrogen/sulfurligand dichlorido-platinum(II) coordination species, which could be responsible for bio-activation of complexes during the longer time-period. From this point of view, the results of interaction studies support an idea that the studied complexes might be considered as possible pro-drugs. However, to validate such an assumption, the more sophisticated and advanced mechanistic studies have to be undertaken.

\section{Supplementary Materials}

Supplementary materials can be accessed at: http://www.mdpi.com/1420-3049/18/6/6990/s1.

\section{Acknowledgments}

The authors gratefully thank the Czech Science Foundation (GAČR P207/11/0841), Operational Program Research and Development for Innovations - European Regional Development Fund (CZ.1.05/2.1.00/03.0058), Operational Program Education for Competitiveness - European Social Fund (CZ.1.07/2.3.00/20.0017) of the Ministry of Education, Youth and Sports of the Czech Republic and Palacký University in Olomouc (PrF_2013_015). 


\section{Conflict of Interest}

The authors declare no conflict of interest.

\section{References}

1. Evaluate Ltd. EvaluatePharma ${ }^{\circledR}$ Coverage of Marketed and Pipeline Products (Platinum Compounds). Available online: http://www.evaluategroup.com/Universal/View.aspx?type $=$ Entity\&entityType $=$ Product $\& 1$ Type $=$ modData\&id $=438 \&$ componentID $=1003 /$ (accessed on 24 April 2013).

2. Kauffmann, G.B.; Pentimalli, R.; Doldi, S.; Hall, M.D. Michele Peyrone (1813-1883), Discoverer of Cisplatin. Platinum Metals Rev. 2010, 54, 250-256.

3. Rosenberg, B.; VanCamp, L.; Trosko, J.E.; Mansour, V.H. Platinum compounds: A new class of potent antitumour agents. Nature 1969, 222, 385-386.

4. Perez, J.M.; Fuertes, M.A.; Alonso, C.; Navarro-Ranninger, C. Current status of the development of trans-platinum antitumor drugs. Crit. Rev. Oncol./Hematol. 2000, 35, 109-120.

5. Kalinowska-Lis, U.; Ochocki, J.; Matlawska-Wasowska, K. Trans geometry in platinum antitumor complexes. Coord. Chem. Rev. 2008, 252, 1328-1345.

6. Farrell, N.; Ha, T.T.B.; Souchard, J.P.; Wimmer, F.L.; Cros, S.; Johnson, N.P. Cytostatic transplatinum(II) complexes. J. Med. Chem. 1989, 32, 2240-2241.

7. Montero, E.I.; Díaz, S.; González-Vadillo, A.M.; Pérez, J.M.; Alonso, C.; Navarro-Ranninger, C. Preparation and characterization of novel trans-[ $\mathrm{PtCl}_{2}$ (amine)(isopropylamine)] compounds. Cytotoxic activity and apoptosis induction in ras-transformed cells. J. Med. Chem. 1999, 42, 4264-4268.

8. Bocarelli, A.; Coluccia, M.; Intini, F.P.; Natile, G.; Locker, D.; Leng, M. Cytotoxicity and DNA binding mode of new platinum-iminoether derivatives with different configuration of the iminoether ligands. Anti-Cancer Drug Des. 1999, 14, 253-264.

9. Coluccia, M.; Nassi, A.; Bocarelli, A.; Giordano, D.; Cardellicchio, N.; Locker, D.; Leng, M.; Sivo, M.; Intini, F.P.; Natile, G. In vitro and in vivo antitumor activity of and cellular pharmacological properties of new platinum-iminoether complexes with different configuration of the iminoether ligands. J. Inorg. Biochem. 1999, 77, 31-35.

10. Perego, P.; Caserini, C.; Gatti, L.; Carenni, N.; Romanelli, S.; Supino, R.; Colangelo, D.; Viano, Y.; Leone, R.; Spinelli, S.; et al. A novel trinuclear platinum complex overcomes cisplatin resistance in an osteosarcoma cell system. Mol. Pharm. 1999, 55, 528-534.

11. Skoog, F.; Hamzi, H.G.; Szweykowska, A.M.; Leonard, N.J.; Carraway, K.L.; Fujii, T.; Helgeson, J.P.; Loeppky, R.N. Cytokinins: Structure/activity relationships. Phytochemistry 1967, 6, 1169-1192.

12. Doležal, K.; Popa, I.; Zatloukal, M.; Lenobel, R.; Hradecká, D.; Vojtěšek, B.; Uldrijan, S.; Mlejnek, P.; Werbrouck, S.; Strnad, M. Substitution derivatives of N6-benzyladenosine, methods of their preparation, their use for preparation of drugs, cosmetic preparations and growth regulators, pharmaceutical preparations, cosmetic preparations and growth regulators containing these compounds. U.S. Patent 8,119,614 B2. 21 February 2012. 
13. Doležel, P.; Koudelková, P.; Mlejnek, P. Halogenation of N6-benzyladenosine decreases its cytotoxicity in human leukemia cells. Toxicol. In Vitro 2010, 24, 2079-2083.

14. Waysbort, D.; Tarien, E.; Eichhorn, G.L. Nature of the specific interaction of rhodium acetate dimer with adenosine. Inorg. Chem. 1993, 32, 4774-4779.

15. Trávníček, Z.; Mikulík, J.; Čajan, M.; Zbořil, R.; Popa, I. Novel iron complexes bearing N6-substituted adenosine derivatives: Synthesis, magnetic, ${ }^{57} \mathrm{Fe}$ Mossbauer, DFT, and in vitro cytotoxicity studies. Bioorg. Med. Chem. 2008, 16, 8719-8728.

16. Szüčová, L.; Trávníček, Z.; Popa, I.; Marek, J. Preparation and cis-to-trans transformation study of square-planar $\left[\mathrm{Pt}\left(\mathrm{L}_{\mathrm{n}}\right)_{2} \mathrm{Cl}_{2}\right]$ complexes bearing cytokinins derived from 6-benzylaminopurine $\left(\mathrm{L}_{\mathrm{n}}\right)$ by view of NMR spectroscopy and X-ray crystallography. Polyhedron 2008, 27, 2710-2720.

17. Štarha, P.; Trávníček, Z.; Popa, A.; Popa, I.; Muchová, T.; Brabec, V. How to modify 7-azaindole to form cytotoxic $\mathrm{Pt}(\mathrm{II})$ complexes: Highly in vitro anticancer effective cisplatin derivatives involving halogeno-substituted 7-azaindole. J. Inorg. Biochem. 2012, 115, 57-63.

18. Geary, W.J. The use of conductivity measurements in organic solvents for the characterization of coordination compounds. Coord. Chem. Rev. 1971, 7, 81-122.

19. Pouchert, C.J. The Aldrich Library of Infrared Spectra; Aldrich Chemical Company Press: Milwaukee, WI, USA; 1981.

20. Čajan, M.; Trávníček, Z. Structural (X-ray), spectral (FT-IR and Raman) and quantum chemical investigations of a series of 6-benzylaminopurine derivatives. J. Mol. Struct. 2011, 994, 350-359.

21. Nakamoto, K. Infrared and Raman Spectra of Inorganic and Coordination Compounds. Part B: Applications in Coordination, Organometallic and Bioinorganic Chemistry; John Wiley \& Sons Ltd.: New York, NY, USA; 1991.

22. Terzis, A.; Hadjiliadis, N.; Rivest, R.; Theophanides, T. X-ray crystal structure of a platinum-9methyladenine complex. Inorg. Chim. Acta 1975, 12, L5-L6.

23. Wexselblatt, E.; Gibson, D. What do we know about the reduction of Pt(IV) pro-drugs? J. Inorg. Biochem. 2012, 117, 220-229.

24. Sanchez-Canoa, C.; Hannon, M.J. Novel and emerging approaches for the delivery of metallo-drugs. Dalton Trans. 2009, 10702-10711.

25. Chung, J.S.; Haque, R.; Guha Mazumder, D.N.; Moore, L.E.; Ghosh, N.; Samanta, S.; Mitra, S.; Hira-Smith, M.M.; von Ehrenstein, O.; Basu, A.; et al. Blood concentrations of methionine, selenium, beta-carotene, and other micronutrients in a case-control study of arsenic-induced skin lesions in West Bengal, India. Environ. Res. 2006, 101, 230-237.

26. Videhult, P.; Laurell, G.; Wallin, I.; Ehrsson, H. Kinetics of cisplatin and its monohydrated complex with sulfur-containing compounds designed for local otoprotective administration. Exp. Biol. Med. 2006, 231, 1638-1645.

27. Farrell, N.; Kelland, L.R.; Roberts, J.D.; Van Beusichem, M. Activation of the trans geometry in platinum antitumor complexes: a survey of the cytotoxicity of trans complexes containing planar ligands in murine L1210 and humar tumor panels and studies on their mechanism of action. Cancer Res. 1992, 52, 5065-5072.

28. Kuhnle, J.A.; Fuller, G.; Corse, J.; Mackey, B.E. Anti-senescent activity of natural cytokinins. Physiol. Plantarum 1977, 41, 14-21. 
29. Novikov, A.V.; Bublyaev, R.A.; Krasnov, N.V.; Kozmin, Y.P.; Mirgorodskaya, O.A. ESI-MS studies of silver ion competitive interaction with cysteine-containing peptides and sulfur-containing amino acids. Protein Pept. Lett. 2010, 17, 1392-1397.

30. Canon, F.; Paté, F.; Meudec, E.; Marlin, T.; Cheynier, V.; Giuliani, A.; Sarni-Manchado, P. Characterization, stoichiometry, and stability of salivary protein-tannin complexes by ESI-MS and ESI-MS/MS. Anal. Bioanal. Chem. 2009, 395, 2535-2545.

31. Sandercock, A.; Robinson, C. Electrospray Ionization Mass Spectrometry and the Study of Protein Complexes. In Protein Interactions; Schuck, P., Ed.; Springer: New York, NY, USA, 2007; Volume 1, pp. 447-468.

Sample Availability: Samples of the compounds 1-13 are available from the authors.

(C) 2013 by the authors; licensee MDPI, Basel, Switzerland. This article is an open access article distributed under the terms and conditions of the Creative Commons Attribution license (http://creativecommons.org/licenses/by/3.0/). 